\title{
Pertumbuhan dan Produksi Dioscorea sansibarensis Pax pada Perlakuan Panjang Lanjaran dan Waktu Batang Membelit
}

\author{
Growth and Yield of Dioscorea sansibarensis Pax on Stake \\ Length and Time of Stem Twining Treatments
}

\author{
Solikin \\ Balai Konservasi Tumbuhan Kebun Raya Purwodadi LIPI \\ J1. Raya Surabaya-Malang Km. 65 Purwodadi, Pasuruan 67163, Indonesia \\ Diterima 26 September 2016/Disetujui 31 Oktober 2017
}

\begin{abstract}
Dioscorea is potentially used as staple food to support food security. The research was aimed to determine the effect of stake length and time of stem twining on the growth of Dioscorea sansibarensis Pax. The experiment was conducted in Purwodadi Botanic Garden from December 2014 until May 2015 using split plot randomized block design consisted of two factors, i.e. the stake length and time of stem twining. The stake length was the main plot consisted of $150 \mathrm{~cm}, 100 \mathrm{~cm}$ and $50 \mathrm{~cm}$ above soil surface and without stake (control). The time of stem twining as subplots, i.e. stem twined early, twined at the time of 4 leaves stage, and twined at 8 leaves stage. Each combination of the treatments was replicated three times. The results showed that there was significant effect on the stake length and the time of stem twining treatments on the plant growth and yield. The stake length of $150 \mathrm{~cm}$ treatment produced the highest fresh tuber and total plant dry weight, i.e., $257.24 \mathrm{~g}$ and $132.77 \mathrm{~g}$ per plant, respectively. On the contrary, the plant without stake produced the lowest fresh tuber and total dry weight of plant, i.e., $112.10 \mathrm{~g}$ and $48.65 \mathrm{~g}$ per plant, respectively.
\end{abstract}

Keywords: biomass, leaf area, photosyntesis, tuber weight

\section{ABSTRAK}

Dioscorea memiliki potensi sebagai sumber pangan untuk mendukung ketahanan pangan. Penelitian yang bertujuan untuk menentukan pengaruh panjang lanjaran dan waktu batang membelit terhadap pertumbuhan Dioscorea sansibarensis Pax. telah dilakukan di Kebun Raya Purwodadi mulai bulan Desember 2014 hingga Mei 2015 dengan menggunakan rancangan acak kelompok petak terbagi yang terdiri atas dua faktor, yaitu panjang lanjaran dan waktu batang membelit. Panjang lanjaran sebagai petak utama meliputi $150 \mathrm{~cm}, 100 \mathrm{~cm}$ dan $50 \mathrm{~cm}$ dari permukaan tanah serta tidak diberi lanjaran (kontrol). Waktu batang membelit sebagai anak petak meliputi batang langsung membelit, batang dibelitkan saat berdaun 4 dan batang dibelitkan saat berdaun 8. Masing-masing kombinasi perlakuan diulang tiga kali. Hasil percobaan menunjukkan bahwa perlakuan panjang lanjaran dan waktu batang membelit pada lanjaran berpengaruh nyata terhadap pertumbuhan dan produksi umbi tanaman. Perlakuan panjang lanjaran $150 \mathrm{~cm}$ menghasilkan berat segar umbi dalam tanah dan berat kering total tanaman tertinggi masing-masing $257.24 \mathrm{~g}$ per tanaman dan $132.77 \mathrm{~g}$ per tanaman. Tanaman tanpa lanjaran menghasilkan berat basah umbi dalam tanah dan berat kering total terendah masing-masing $112.10 \mathrm{~g}$ per tanaman dan $48.65 \mathrm{~g}$ per tanaman.

Kata kunci: berat umbi, biomassa, fotosintesis, luas daun

\section{PENDAHULUAN}

Dioscorea spp. yang dikenal dengan nama 'gadunggadungan' termasuk suku Dioscoreaceae yang telah lama dimanfaatkan sebagai sumber pangan penduduk di beberapa negara di dunia termasuk Indonesia. Tanaman ini berpotensi dikembangkan menjadi komoditas pangan

\footnotetext{
* Penulis untuk korespondensi. e-mail: lipisolikin@gmail.com
}

untuk menunjang keragaman dan ketahanan pangan. Walaupun demikian, budidaya dan pengembangannya di Indonesia kurang mendapat perhatian sehingga informasi tentang budidaya dan produksinya masih sedikit (Sulistyono dan Marpaung, 2004).

Dioscorea spp. telah menjadi sumber bahan pangan yang memiliki nilai ekonomi penting dan telah dibudidayakan secara luas di Afrika (Adewale, 2010, Adewale dan Dumet, 2011), bahkan Ghana telah menjadi 
pengekspor produk tanaman ini (Danquah et al., 2015). Umbinya merupakan sumber protein, serat dan mineral yang penting, selain karbohidrat (Ogah, 2013) dan sangat baik digunakan sebagai makanan bagi penderita diabetes (Sunarsih et al., 2007) karena memiliki indeks glikemik yang rendah yaitu sekitar 5.1 dibanding nasi dan kentang yang masing-masing memiliki indeks glikemik 72 dan 54 (Maulidia dan Estiasih, 2014). Kandungan protein Dioscorea esculenta dapat mencapai 5.57\% (Sulistyono dan Marpaung, 2004).

Salah satu kendala produksi Dioscorea spp adalah rendahnya hasil umbi tanaman (Saka et al., 2007) yang disebabkan oleh teknik budidaya yang kurang tepat (Ogah, 2013). Pemberian lanjaran sangat penting untuk meningkatkan pertumbuhan dan hasil umbi tanaman ini (Adeniyan et al., 2007; Otoo, 2008; Law-Ogbomo dan Remison, 2008; Tsado, 2012; Ennin et al., 2014; Danquah et al., 2015) karena tumbuhnya memanjat atau membelit hingga 1.5-3.0 m (Ogah, 2013). Penurunan hasil dapat mencapai $37-65 \%$ pada tanaman yang tidak diberi lanjaran (Danquah et al., 2015).

Dioscorea spp. yang ditanam petani pada umumnya membelit secara alami pada beragam jenis pohon yang berada di sekitarnya seperti lamtoro, gamal, sengon dan mahoni. Beberapa petani di beberapa daerah seperti di Jawa dan Madura juga telah memberi lanjaran bambu pada budidaya $D$. alata L. dan D. esculenta (Lour.) Burk. dengan panjang yang beragam. Pemberian lanjaran terbukti telah meningkatkan hasil tanaman Luffa acutangula L. Roxb (Hilli et al., 2009).

Pemberian lanjaran pada tanaman perlu disesuaikan dengan karakteristik pertumbuhan masing-masing jenis tanaman, baik panjang atau bentuknya untuk mendapatkan pertumbuhan tanaman secara maksimal. Chukwudi dan Agbo (2014) melaporkan bahwa total hasil bobot daun pada tanaman Telfaira occidentale Hook F. yang diberi lanjaran $90 \mathrm{~cm}$ memberikan hasil lebih tinggi daripada tanaman diberi lanjaran $45 \mathrm{~cm}$ atau tanpa lanjaran. Penelitian ini bertujuan untuk mempelajari pengaruh panjang lanjaran dan waktu membelit batang terhadap pertumbuhan tanaman Dioscorea sansibarensis Pax.

\section{BAHAN DAN METODE}

Penelitian dilakukan di Kebun Raya Purwodadi mulai bulan Desember 2014 sampai Mei 2015 dengan menggunakan rancangan acak kelompok petak terbagi yang terdiri atas dua faktor, yaitu panjang lanjaran dan waktu batang membelit. Panjang lanjaran sebagai petak utama meliputi $50 \mathrm{~cm}, 100 \mathrm{~cm}$, dan $150 \mathrm{~cm}$ dari permukaan tanah dan tidak diberi lanjaran (panjang lanjaran $0 \mathrm{~cm}$ ). Waktu batang membelit sebagai anak petak meliputi batang dibelitkan sejak awal pertumbuhan, batang dibelitkan saat berdaun 4 helai dan batang dibelitkan saat berdaun 8 helai. Masing-masing kombinasi perlakuan panjang lanjaran 50 $\mathrm{cm}, 100 \mathrm{~cm}$, dan $150 \mathrm{~cm}$ dan batang dibelitkan sejak awal pertumbuhan, batang dibelitkan saat berdaun 4 helai dan batang dibelitkan saat berdaun 8 helai diulang tiga kali.
Perlakuan kontrol adalah perlakuan panjang lanjaran $0 \mathrm{~cm}$ dan batang tidak dibelitkan dengan tiga kali pengulangan. Keseluruhan ada 30 satuan percobaan.

Penanaman diawali dengan menyemaikan umbi udara Dioscorea zansibarensis Pax sebobot 7-10 g per umbi di dalam kantong plastik hitam. Setelah umbi bertunas, ditanam sedalam pangkal tunas dalam polibag (ukuran $25 \times 25 \mathrm{~cm} \times 0.06 \mathrm{~mm}$ ) yang berisi media tanah katel (tanah hasil sedimentasi sungai), masing-masing berisi satu umbi. Polibag ditata dengan jarak antar tepi polibag $30 \mathrm{~cm}$ dalam baris dan $50 \mathrm{~cm}$ antar baris; jarak antar petak $100 \mathrm{~cm}$. Lanjaran ditancapkan disamping polibag sedalam sekitar $15 \mathrm{~cm}$. Selama pertumbuhan tanaman, batang dibelitkan sesuai dengan perlakuan. Batang dibelitkan ke arah kiri searah dengan putaran jarum jam, disesuaikan dengan karakteristik pertumbuhan batangnya. Batang yang membelit diikat dengan tali rafia agar dapat membelit dengan kuat dan tidak roboh. Pengamatan dilakukan terhadap panjang tanaman, jumlah daun, jumlah umbi udara, luas daun, dan bobot tanaman.

Panjang tanaman, jumlah daun, dan jumlah umbi udara diamati setiap minggu pada awal pengamatan hingga umur 27 hari setelah tanam (HST), kemudian dilanjutkan setiap dua minggu; khusus panjang tanaman, pengamatan diakhiri hingga umur 27 HST karena setelah itu secara teknis pengukuran sulit dilakukan. Panjang tanaman diukur dengan bantuan tali yang dibelitkan sesuai dengan arah belit batang hingga ujung tanaman terpanjang. Jumlah daun dihitung berdasarkan helai daun yang telah membuka penuh. Jumlah umbi udara dihitung mulai terbentuk umbi udara hingga terbentuk sempurna di ketiak daun. Pengukuran luas daun dengan menggunakan metode punch (Agustina, 2004) dengan rumus :

Luas daun $=\underline{\mathrm{a}+\mathrm{b}} \times \mathrm{c}$ $\mathrm{a} / \mathrm{n}$

$\mathrm{a}$ : bobot kering bulatan daun $(\mathrm{g})$

$\mathrm{b}$ : bobot kering daun berlubang $(\mathrm{g})$

$\mathrm{n}$ : jumlah bulatan daun (setiap perlakuan 30 bulatan, terdiri 10 bagian pangkal, 10 bagian tengah dan 10 bagian ujung helai daun)

c : luas setiap lubang $\left(\mathrm{cm}^{2}\right)$

Pengamatan bobot kering, luas daun, dan bobot segar umbi dalam tanah dilakukan pada akhir pengamatan. Bobot kering ditentukan dengan menimbang biomassa (batang, daun, umbi udara, umbi dalam tanah dan akar) setelah dioven selama $3 \times 24$ jam (atau tergantung jenis materialnya) pada suhu $80{ }^{\circ} \mathrm{C}$. Pengeringan umbi udara dan umbi dalam tanah dilakukan dengan membelah atau mengiris umbi terlebih dahulu hingga berukuran kecil-kecil untuk mempercepat pengeringan. Bobot segar umbi dalam tanah ditimbang setelah umbi dibersihkan dari tanah dan akar yang melekat.

Pemeliharaan tanaman meliputi penyiangan gulma yang tumbuh di sekitar tanaman; pemupukan dilakukan hanya dengan memberikan pupuk urea pada umur sekitar 2 bulan setelah tanam dengan dosis 5 g per tanaman di sebar pada jarak sekitar $7 \mathrm{~cm}$ dari batang, kemudian disiram air. 


\section{HASIL DAN PEMBAHASAN}

Pembelitan jenis tanaman membelit pada lanjaran dapat meningkatkan fotosintesis tanaman melalui penangkapan cahaya oleh tanaman secara optimal melalui posisi daun yang tumbuh secara vertikal dan pengurangan penaungan antar daun dalam satu tanaman. Hasil penelitian menunjukkan bahwa terdapat pengaruh interaksi yang nyata antara perlakuan panjang lanjaran dan saat batang membelit atau dibelitkan terhadap peubah jumlah daun, bobot kering daun, luas daun, jumlah umbi udara, bobot kering umbi udara dan akar tanaman (Tabel 1). Pengaruh interaksi kedua perlakuan tidak nyata terhadap bobot kering batang, bobot kering dan bobot basah umbi dalam tanah serta bobot kering total tanaman, namun masing-masing perlakuan memberikan pengaruh yang nyata terhadap peubah-peubah ini (Tabel 2, Tabel 3). Pengaruh interaksi kedua perlakuan tidak nyata terhadap panjang tanaman hingga umur 27 hari setelah tanam (HST) (Tabel 1).

\section{Pertumbuhan Tanaman}

Luas daun adalah salah satu faktor penting dalam pertumbuhan dan produksi tanaman karena berkaitan dengan besarnya intensitas cahaya yang diterima dan fotosintesis tanaman untuk pertumbuhan dan produksi tanaman. Enyi (2008) melaporkan bahwa luas daun yang besar dapat meningkatkan pertumbuhan daun, batang dan umbi pada D. esculenta. Perbedaan luas daun menyebabkan perbedaan pertumbuhan dan hasil tanaman seperti ditunjukkan Gambar 1 bahwa peningkatan luas daun pada tanaman $D$. sansibarensis diikuti oleh meningkatnya bobot kering total $\left(\mathrm{y}=0.017 \mathrm{x}+25.76, \mathrm{R}^{2}=0.996\right)($ Gambar 1B) dan bobot kering umbi $\left(\mathrm{y}=32.28 \ln (\mathrm{x})-198.2, \mathrm{R}^{2}=0.996\right)($ Gambar 1C).

Peningkatan panjang lanjaran dari perlakuan $0 \mathrm{~cm}$ hingga $150 \mathrm{~cm}$ diikuti oleh peningkatan pertumbuhan luas daun dengan persamaan $\mathrm{y}=935.9 \ln (\mathrm{x})+2103, \mathrm{R}^{2}=0.981$ (Gambar 1A). Oleh sebab itu pada perlakuan tanaman diberi lanjaran $150 \mathrm{~cm}$ dan membelit sejak awal yang mempunyai luas daun tertinggi $\left(9,609 \mathrm{~cm}^{2}\right.$ per tanaman) menghasilkan bobot kering daun, bobot kering akar, bobot kering umbi udara, jumlah daun dan panjang tanaman tertinggi, yaitu masing-masing $24.02 \mathrm{~g}, 21.31 \mathrm{~g}, 11.80 \mathrm{~g}, 55.67$ helai dan $115.67 \mathrm{~cm}$ (Tabel 1). Sebaliknya, tanaman tanpa lanjaran dan dibiarkan menjalar tanpa membelit yang mempunyai luas daun paling kecil $\left(1,521 \mathrm{~cm}^{2}\right.$ per tanaman) menghasilkan pertumbuhan bobot kering daun, bobot kering akar, bobot kering umbi udara, jumlah daun dan panjang tanaman paling rendah di antara perlakuan lainnya, yaitu masing-masing

Tabel 1. Rata-rata hasil per tanaman Dioscorea sansibarensis Pax pada perlakuan panjang lanjaran dan waktu batang membelit pada akhir pengamatan

\begin{tabular}{|c|c|c|c|c|c|c|c|}
\hline \multirow[b]{2}{*}{ Perlakuan } & \multicolumn{3}{|c|}{ Daun } & \multicolumn{2}{|c|}{ Umbi udara } & \multirow{2}{*}{$\begin{array}{l}\text { Bobot } \\
\text { kering } \\
\text { akar } \\
(\mathrm{g})\end{array}$} & \multirow[b]{2}{*}{$\begin{array}{c}\text { Panjang } \\
\text { tanaman } \\
(\mathrm{cm})^{*}\end{array}$} \\
\hline & $\begin{array}{c}\text { Bobot } \\
\text { kering } \\
(\mathrm{g})\end{array}$ & $\begin{array}{l}\text { Jumlah } \\
\text { (helai) }\end{array}$ & $\begin{array}{l}\text { Luas } \\
\left(\mathrm{cm}^{2}\right)\end{array}$ & $\begin{array}{l}\text { Jumlah } \\
\text { (umbi) }\end{array}$ & $\begin{array}{l}\text { Bobot } \\
\text { kering } \\
\text { (g) }\end{array}$ & & \\
\hline $\begin{array}{l}\text { Kontrol (Panjang lanjaran } 0 \mathrm{~cm} \\
\text { dan batang tidak membelit }\end{array}$ & $3.80 \mathrm{a}$ & $16.67 \mathrm{a}$ & $1,521 \mathrm{a}$ & $7.50 \mathrm{a}$ & $2.47 \mathrm{a}$ & $6.63 a$ & $93.50 \mathrm{a}$ \\
\hline $\begin{array}{l}\text { Panjang lanjaran } 150 \mathrm{~cm} \text { dan } \\
\text { batang membelit sejak awal }\end{array}$ & $24.02 \mathrm{c}$ & $55.67 \mathrm{c}$ & $9,609 \mathrm{c}$ & $10.83 \mathrm{ab}$ & $11.18 \mathrm{c}$ & $21.31 \mathrm{c}$ & $115.67 \mathrm{a}$ \\
\hline $\begin{array}{l}\text { Panjang lanjaran } 150 \mathrm{~cm} \text { dan } \\
\text { batang membelit saat berdaun } 4\end{array}$ & $17.94 \mathrm{bc}$ & $35.00 \mathrm{~b}$ & $7,177 \mathrm{bc}$ & $14.17 b$ & $11.14 \mathrm{c}$ & $12.23 b$ & $96.50 \mathrm{a}$ \\
\hline $\begin{array}{l}\text { Panjang lanjaran } 150 \mathrm{~cm} \text { dan } \\
\text { batang membelit saat berdaun } 8\end{array}$ & $12.36 \mathrm{~b}$ & $33.33 b$ & $4,943 b$ & $15.17 b$ & $8.23 b c$ & $8.40 \mathrm{a}$ & $75.50 \mathrm{a}$ \\
\hline $\begin{array}{l}\text { Panjang lanjaran } 100 \mathrm{~cm} \text { dan } \\
\text { batang membelit sejak awal }\end{array}$ & $17.03 \mathrm{bc}$ & $49.00 \mathrm{~cd}$ & $6,811 b c$ & $16.83 b$ & $9.38 \mathrm{c}$ & $11.81 \mathrm{~b}$ & $112.33 \mathrm{a}$ \\
\hline $\begin{array}{l}\text { Panjang lanjaran } 100 \mathrm{~cm} \text { dan } \\
\text { batang membelit saat berdaun } 4\end{array}$ & $16.89 \mathrm{bc}$ & $37.67 \mathrm{~b}$ & $6,755 \mathrm{bc}$ & $17.17 \mathrm{~b}$ & $8.63 b c$ & $10.15 b$ & $122.33 a$ \\
\hline $\begin{array}{l}\text { Panjang lanjaran } 100 \mathrm{~cm} \text { dan } \\
\text { batang membelit saat berdaun } 8\end{array}$ & $12.13 b$ & $30.67 \mathrm{a}$ & $4,853 b$ & $17.50 \mathrm{~b}$ & $10.48 \mathrm{c}$ & $9.69 \mathrm{~b}$ & $96.67 \mathrm{a}$ \\
\hline $\begin{array}{l}\text { Panjang lanjaran } 50 \mathrm{~cm} \text { dan } \\
\text { batang membelit sejak awal }\end{array}$ & $15.32 b$ & $38.33 b$ & $6,128 b$ & $17.50 \mathrm{~b}$ & $9.67 \mathrm{c}$ & $10.61 \mathrm{~b}$ & $109.17 \mathrm{a}$ \\
\hline $\begin{array}{l}\text { Panjang lanjaran } 50 \mathrm{~cm} \text { dan } \\
\text { batang membelit saat berdaun } 4\end{array}$ & $12.53 b$ & $34.33 b$ & $5,013 b$ & $18.67 \mathrm{~b}$ & $7.58 \mathrm{bc}$ & $8.75 b$ & $91.00 \mathrm{a}$ \\
\hline $\begin{array}{l}\text { Panjang lanjaran } 50 \mathrm{~cm} \text { dan } \\
\text { batang membelit saat berdaun } 8\end{array}$ & $13.58 b$ & $36.17 b$ & $5,431 b$ & $18.67 \mathrm{~b}$ & $5.19 \mathrm{ab}$ & $7.05 \mathrm{a}$ & $90.17 \mathrm{a}$ \\
\hline
\end{tabular}

Keterangan: Angka yang diikuti huruf yang sama pada kolom yang sama menunjukkan hasil yang tidak berbeda nyata DMRT pada $\alpha=$ $5 \%$. $*$ pengamatan umur 27 hari setelah tanam 
Tabel 2. Bobot hasil per tanaman D. sansibarensis Pax pada perlakuan panjang lanjaran

\begin{tabular}{|c|c|c|c|c|c|c|c|}
\hline \multirow[b]{2}{*}{ Perlakuan } & \multicolumn{6}{|c|}{ Bobot kering (g per tanaman) } & \multirow{2}{*}{$\begin{array}{c}\text { Bobot basah } \\
\text { umbi dalam } \\
\text { tanah } \\
\text { (g per tanaman) }\end{array}$} \\
\hline & Akar & Batang & Daun & $\begin{array}{l}\text { Umbi } \\
\text { udara }\end{array}$ & $\begin{array}{l}\text { Umbi } \\
\text { dalam } \\
\text { tanah }\end{array}$ & Total * & \\
\hline Panjang lanjaran $150 \mathrm{~cm}$ & $13.98 \mathrm{c}$ & $22.38 b$ & $17.86 \mathrm{~b}$ & $10.48 \mathrm{c}$ & $68.07 \mathrm{~b}$ & $132.77 b$ & $257.24 b$ \\
\hline Panjang lanjaran $100 \mathrm{~cm}$ & $10.55 \mathrm{c}$ & $18.04 \mathrm{~b}$ & $15.31 \mathrm{~b}$ & $9.50 \mathrm{c}$ & $64.60 \mathrm{~b}$ & $118.00 \mathrm{~b}$ & $242.33 b$ \\
\hline Panjang lanjaran $50 \mathrm{~cm}$ & $8.80 \mathrm{~b}$ & $18.60 \mathrm{~b}$ & $13.87 \mathrm{~b}$ & $7.48 \mathrm{~b}$ & $59.82 b$ & $108.58 \mathrm{~b}$ & $239.08 b$ \\
\hline Tanpa lanjaran & $3.80 \mathrm{a}$ & $8.48 \mathrm{a}$ & $3.80 \mathrm{a}$ & $2.47 \mathrm{a}$ & $30.10 \mathrm{a}$ & $48.65 \mathrm{a}$ & $112.10 \mathrm{a}$ \\
\hline
\end{tabular}

Keterangan: Angka yang diikuti huruf yang sama pada kolom yang sama menunjukkan hasil yang tidak berbeda nyata berdasarkan perbandingan ortogonal pada $\alpha=5 \%$. = Bobot kering total adalah hasil penjumlahan bobot kering akar, batang, daun, umbi udara dan umbi dalam tanah

$3.80 \mathrm{~g}, 6.63 \mathrm{~g}, 2.47 \mathrm{~g}, 16.67$ helai dan $93.50 \mathrm{~cm}$ (Tabel 1). Ennin et al. (2014) juga membuktikan bahwa tanaman Dioscorea spp. yang tidak diberi lanjaran menghasilkan panjang batang, jumlah cabang, jumlah daun, luas daun lebih rendah dibanding tanaman diberi lanjaran.

Jenis tanaman membelit seperti Dioscorea spp. perlu diberi lanjaran sebagai tempat membelit batang agar pertumbuhan dan hasil tanaman meningkat. Batang yang secara langsung membelit atau dibelitkan pada lanjaran sejak awal akan tumbuh lebih kuat dan kemungkinan terjadinya hambatan pertumbuhan lebih kecil sehingga pertumbuhan dan hasil tanamannya lebih lebih besar dibanding batang tanaman yang dibelitkan pada saat tanaman berdaun 4 , tanaman berdaun 8 dan tanpa diberi lanjaran (kontrol). Tabel 3 menunjukkan bahwa tanaman yang dibelitkan pada lanjaran sejak awal menghasilkan bobot kering daun, batang dan akar tertinggi yaitu masing-masing 18.72, 23.77 dan
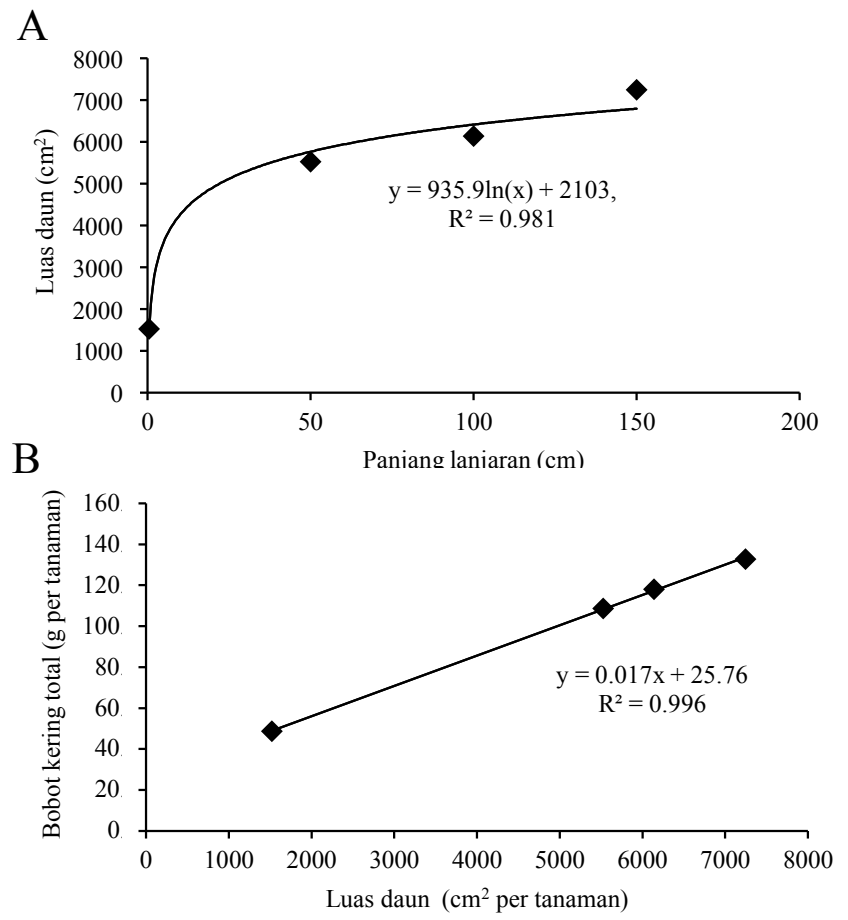

Gambar 1. Hubungan antara panjang lanjaran dan luas daun (A); luas daun dan bobot kering total (B); luas daun dan bobot kering umbi (C); luas daun dan bobot kering umbi udara D. sansibarensis Pax (D)
$14.58 \mathrm{~g}$ per tanaman. Pertumbuhan panjang batang hingga umur 27 HST tidak dipengaruhi oleh perlakuan panjang lanjaran dan waktu batang membelit (Tabel 1), namun dibelitkan lebih awal pada lanjarannya memiliki batang yang lebih panjang dibanding batang yang terlambat membelit atau tidak diberi lanjaran (Tabel 1).

\section{Produksi Umbi}

Umbi adalah bagian penting dari hasil pertumbuhan tanaman Dioscorea spp., baik umbi udara maupun umbi dalam tanah. Bobot umbi udara dan umbi dalam tanah yang dihasilkan tanaman berkaitan dengan besarnya hasil fotosintesis yang dapat disimpan dalam umbi. Makin besar hasil fotosintesis yang disimpan dalam umbi semakin besar umbi yang dihasilkan. Pemasangan lanjaran untuk

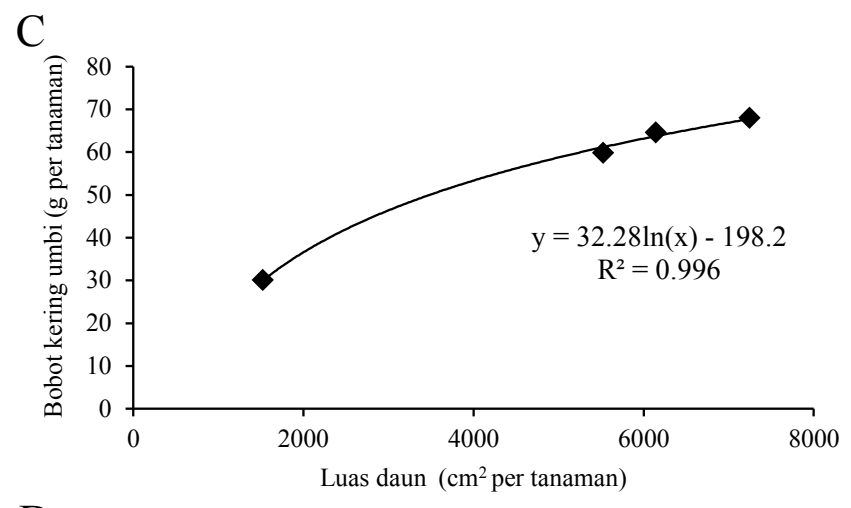

$\mathrm{D}$

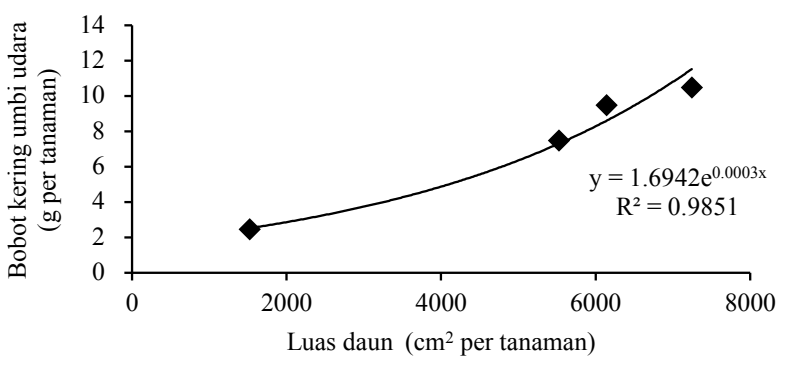
terdapat kecenderungan bahwa batang yang membelit atau 
pembelitan batang pada tanaman Dioscorea spp. dapat meningkatkan jumlah fotosintat yang disimpan dalam umbi sehingga dapat meningkatkan produksi umbi. Bobot umbi segar dan kering dalam tanah pada tanaman diberi lanjaran dan dibelitkan pada lanjaran lebih tinggi dibanding tanaman yang tidak diberi lanjaran dan dibiarkan tumbuh menjalar (Tabel 2, Tabel 3). Pemberian lanjaran pada tanaman dari $50 \mathrm{~cm}$ hingga $150 \mathrm{~cm}$ dapat meningkatkan bobot kering umbi dalam tanah dari $30.10 \mathrm{~g}$ per tanaman (tanpa lanjaran) menjadi $64.60 \mathrm{~g}$ per tanaman dan $68.07 \mathrm{~g}$ per tanaman atau meningkat sebesar $114.27 \%$ dan $126.12 \%$ (Tabel 2). Bobot basah umbi dalam tanah juga meningkat dari $112.10 \mathrm{~g}$ per tanaman (tanpa lanjaran) menjadi 257.24 g per tanaman (panjang lanjaran $150 \mathrm{~cm}$ ). Peningkatan ini disebabkan oleh meningkatnya luas daun tanaman seperti ditunjukkan pada Gambar 1A dan 1C.

Bobot kering umbi yang masih terus meningkat (Gambar 1C) disebabkan oleh peningkatan luas daun yang masih belum mencapai titik optimal sehingga bobot umbi terus meningkat seiring dengan meningkatnya luas daun tanaman. Peningkatan bobot umbi semakin rendah saat luas daun optimal dicapai. Peningkatan panjang lanjaran berperan dalam meningkatkan ruang tumbuh daun dan tanaman serta kapasitas penerimaan intensitas cahaya dalam tanaman sehingga fotosintesis dan pertumbuhan tanaman meningkat termasuk pertumbuhan umbi.

Umbi udara dihasilkan beberapa jenis Dioscorea seperti D. alata L., D. bulbifera L., dan D. pentaphylla L. pada ruas batangnya. Hasil percobaan menunjukkan bahwa bobot kering umbi udara pada tanaman yang diberi lanjaran lebih tinggi dibanding tanaman tanpa diberi lanjaran. Tanaman tanpa diberi lanjaran dan dibiarkan menjalar menghasilkan bobot kering umbi udara $2.47 \mathrm{~g}$ per tanaman, sedangkan tanaman yang diberi lanjaran $50 \mathrm{~cm}$ hingga $150 \mathrm{~cm}$ menghasilkan bobot kering umbi udara $7.48 \mathrm{~g}$ per tanaman hingga $10.48 \mathrm{~g}$ per tanaman atau meningkat dari $202.83 \%$ hingga $324.30 \%$ (Tabel 2). Perbedaan ini disebabkan oleh luas daun dan bobot akar tanaman pada masing-masing perlakuan berbeda sehingga besarnya hasil fotosintesis yang disimpan untuk menghasilkan umbi berbeda. Hubungan antara luas daun dan bobot umbi udara yang dihasilkan tanaman D. sansibarensis Pax pada perlakuan panjang lanjaran dapat ditunjukkan pada Gambar $1 \mathrm{D}$ dengan persamaan $\left(\mathrm{Y}=1.694 \mathrm{e}^{0,000 \mathrm{x}} \quad \mathrm{R}^{2}=0.985 ; \mathrm{Y}=\right.$ bobot kering umbi udara; $\mathrm{X}=$ luas daun).

Jumlah umbi udara terbanyak diperoleh pada tanaman yang diberi lanjaran $50 \mathrm{~cm}$ dan batang dibelitkan sejak awal, panjang lanjaran $50 \mathrm{~cm}$ dan batang dibelitkan saat berdaun 4, dan panjang lanjaran $50 \mathrm{~cm}$ dan batang dibelitkan saat berdaun 8 (Tabel 1). Bobot kering umbi udara per tanaman terbesar diperoleh pada perlakuan panjang lanjaran 150 $\mathrm{cm}$ dan batang dibelitkan sejak awal. Hal ini menunjukkan adanya perbedaan pola dan besarnya translokasi fotosintat menuju calon umbi udara yang berada di ruas batang, pada pangkal tangkai daun. Batang yang membelit pada lanjaran $50 \mathrm{~cm}$ lebih cepat mencapai ujung lanjaran, kemudian ujung batang menjuntai ke bawah. Hal ini dapat memacu translokasi dan penyimpanan fotosintat pada calon-calon umbi udara yang berada di ruas-ruas batang sehingga umbi udara yang dihasilkan lebih banyak, walaupun demikian umbi udara yang dihasilkan berukuran lebih kecil sehingga bobot keringnya rendah (Tabel 1). Pada tanaman yang dibelitkan pada lanjaran $150 \mathrm{~cm}$, fotosintat hasil fotosintesis digunakan terlebih dahulu untuk pertumbuhan batang dan daun. Namun dengan luas daun yang lebih besar pada perlakuan ini, jumlah fotosintat yang dihasilkan dan disimpan dalam umbi udara lebih besar sehingga bobot kering yang dihasilkan lebih besar, seperti ditunjukkan pada Tabel 1.

Tanaman yang dibiarkan menjalar menghasilkan umbi udara paling sedikit di antara perlakuan lainnya. Ini disebabkan oleh luas daun paling rendah (Tabel 1) yang disebabkan oleh adanya kerusakan daun saat musim hujan sehingga fotosintesis dan pertumbuhan tanaman menjadi paling rendah.

\section{Bobot Kering Biomassa}

Pengaruh interaksi antara perlakuan panjang lanjaran dan waktu membelit batang terhadap bobot kering batang dan bobot kering total tanaman tidak nyata, walaupun demikian masing-masing perlakuan berpengaruh nyata terhadap bobot kering biomassa tanaman. Tabel 2 dan Tabel 3 menunjukkan bahwa tanaman yang diberi lanjaran dan

Tabel 3. Bobot hasil per tanaman D. sansibarensis Pax pada perlakuan saat batang membelit

\begin{tabular}{|c|c|c|c|c|c|c|c|}
\hline \multirow[b]{2}{*}{ Perlakuan } & \multicolumn{6}{|c|}{ Bobot kering (g per tanaman) } & \multirow{2}{*}{$\begin{array}{c}\text { Bobot basah } \\
\text { umbi dalam } \\
\text { tanah }\end{array}$} \\
\hline & Akar & Batang & Daun & $\begin{array}{l}\text { Umbi } \\
\text { udara }\end{array}$ & $\begin{array}{l}\text { Umbi } \\
\text { dalam } \\
\text { tanah }\end{array}$ & Total & \\
\hline Batang membelit sejak awal & $14.58 \mathrm{c}$ & $23.77 b$ & $18.72 \mathrm{c}$ & $10.29 b$ & $65.01 \mathrm{~b}$ & $132.36 b$ & $260.49 b$ \\
\hline Batang membelit saat berdaun 4 & $10.38 \mathrm{c}$ & $19.43 b$ & $15.53 \mathrm{c}$ & $9.21 \mathrm{~b}$ & $68.39 b$ & $122.94 b$ & $248.06 b$ \\
\hline Batang membelit saat berdaun 8 & $8.38 b$ & $15.82 b$ & $12.79 b$ & $7.97 \mathrm{~b}$ & $59.08 b$ & $104.04 \mathrm{~b}$ & $230.1 b$ \\
\hline Tanpa membelit & $3.8 \mathrm{a}$ & $8.48 \mathrm{a}$ & $3.8 \mathrm{a}$ & $2.47 \mathrm{a}$ & $30.1 \mathrm{a}$ & $48.65 \mathrm{a}$ & $112.1 \mathrm{a}$ \\
\hline
\end{tabular}

Keterangan: Angka yang diikuti huruf yang sama pada kolom yang sama menunjukkan hasil yang tidak berbeda nyata berdasarkan perbandingan ortogonal pada $\alpha=5 \%{ }^{*}$ ) bobot kering total adalah hasil penjumlahan bobot kering akar, batang, daun, umbi udara dan umbi dalam tanah 
membelit pada lanjaran menghasilkan bobot kering total tanaman lebih tinggi dibanding tanaman tidak diberi lanjaran dan tidak membelit. Tanaman yang tidak diberi lanjaran menghasilkan bobot kering total $48.65 \mathrm{~g}$ per tanaman, sedangkan tanaman yang diberi lanjaran menghasilkan bobot kering total tanaman dari $108.58 \mathrm{~g}$ (panjang lanjaran $50 \mathrm{~cm}$ ) sampai $132.12 \mathrm{~g}$ (panjang lanjaran $150 \mathrm{~cm}$ ) g per tanaman atau meningkat dari $123.39 \%$ sampai $172.90 \%$ (Tabel 2).

Tanaman yang tidak diberi lanjaran atau dibiarkan tumbuh menjalar menghasilkan pertumbuhan paling rendah diantara perlakuan lainnya disebabkan oleh adanya hambatan atau gangguan pertumbuhan tanaman, terutama saat musim hujan, sehingga beberapa daun tidak dapat tumbuh dengan normal atau mati akibat membusuk sehingga jumlah dan luas daun yang dihasilkan lebih rendah. Danquah et al. (2015) melaporkan bahwa hasil total tanaman Dioscorea spp. yang tidak diberi lanjaran lebih rendah dibanding tanaman yang diberi lanjaran. Enyi (2008) juga melaporkan bahwa akumulasi bobot kering tanaman D. esculenta yang tidak diberi lanjaran lebih rendah daripada tanaman yang diberi lanjaran.

\section{KESIMPULAN}

Pemberian lanjaran meningkatkan bobot basah dan bobot kering umbi dalam tanah serta bobot kering tanaman. Semakin panjang lanjaran, bobot kering akar, batang, daun dan umbi udara dan umbi dalam tanah cenderung semakin tinggi. Batang yang dibelitkan meningkatkan bobot basah dan bobot kering tanaman. Semakin awal batang dibelitkan pada lanjaran, bobot kering akar, batang, daun, umbi udara dan bobot basah umbi dalam tanah cenderung makin meningkat.

\section{DAFTAR PUSTAKA}

Adeniyan, O.N., S.R. Akande, M.O. Baogun, J.O.Saka. 2007. Evaluation of crop yield of African yam bean, maize and kenaf under intercropping systems. American-Eurasian J. Agric. Environ. Sci. 1:99-102.

Adewale, D. 2010. African yam bean: a food security crop? IITA Researchr4dreview.org/.../exploiting-thediversity-of-african-yam-bean. [29 Desember 2015].

Adewale, D.B., D.J. Dumet. 2011. Descriptor for African yam bean Sphenostylis stenocarpa (Hochst Ex. A. Rich) Harms. IITA Res. News 1-12.

Agustina, L. 2004. Kajian Pertumbuhan dan Perkembangan Tanaman. Jurusan Budidaya Pertanian. Fakultas Pertanian. Universitas Brawijaya. Malang.

Chukwudi, U.P., C.U. Agbo. 2014. Effect of trellis and cutting frequency on leaf and fruit yield of fluted pumpkin (Telfairia occidentalis Hook F.). J. Anim. Pl. Sci. 24:1190-1197.

Danquah, E.O., S. A. Ennin, J.N. L. Lamptey, P. P. Acheampong. 2015. Staking options for sustainable yam production in Ghana. Sust. Agric.Res. 4:106113.

Ennin, I.A., R.N. Issaka, P.P. Acheampong, M. Numafo, E.O. Danquah. 2014. Mechanization, fertilization and staking options for environmentally sound yam production. Afr. J. Agr. Res. 9:2222-2230.

Enyi, B.A.C. 2008. Effect of staking, nitrogen and potassium on growth and development in lesser yams: Dioscorea esculenta. Ann. Appl. Biol. 2:211-219.

Hilli, J. S., B. S. Vyakarnahal, D. P. Biradar, R. Hunje. 2009. Influence of method of trailing and fertilizer levels on seed yield of ridge gourd (Luffa acutangula L. Roxb). Karnataka J. Agric. Sci. 22:47-52.

Law-Ogbomo, K.E., S.U. Remison. 2008. Growth and yield of white guinea yam(Dioscorea rotundata Poir.) influenced by NPK fertilization on a forest site in Nigeria. J. Trop. Agric. 46:21-24.

Maulidia, D., T. Estiasih. 2014. Efek hipoglikemik polisakarida larut air umbi gadung dan alginat: Kajian pustaka. J. Pangan Agroindustri 2:136-140.

Ogah, E.O. 2013. Evaluating the effects of staking and planting dates on the yields of African yam bean, Sphenostylis stenocarpa in Nigeria. Amer. J. Exp. Agric.3:731-739.

Otoo, J.A., 2008. Effects of staking, fertilizer and spacing on seed yam yields. Ghana J. Agric. Sci. 1:101-105.

Saka, J.O., O.N. Adeniyan, S.R. Akande, M.O. Balogun. 2007. An economic evaluation of intercropping African yam bean, kenaf and maize in the rain forest zone of Nigeria. Middle-East J. Sci. Res. 2:01-08.

Sulistyono, E., J. Marpaung. 2004. Studi karakter umbi dan kandungan nutrisi Dioscorea spp. Bul. Agron. 32:3943.

Sunarsih, E.S., Djatmika, R.S. Utoma. 2007. Pengaruh pemberian infusa umbi gadung (Dioscorea hispida Dennst.) terhadap penurunan kadar glukosa darah tikus putih. Majalah Farmasi Indonesia 18:29-33.

Tsado, E.K. 2012. Substituting wooden sticks with plastic stakes in yam production in in Niger State, Nigeria. J. Nat. Sci. Res. 2:88-96. 